\title{
OPTIMALISASI KETERAMPILAN PEMBELAJARAN ABAD 21 DALAM PROSES PEMBELAJARAN PADA GURU MTS MASSARATUL MUT'ALLIMIN BANTEN
}

\author{
Beni Junedi ${ }^{1}$, Isnaini Mahuda ${ }^{1}$, Jaka Wijaya Kusuma ${ }^{1}$ \\ ${ }^{1}$ Universitas Bina Bangsa, Serang, Indonesia \\ beni.junedi@binabangsa.ac.id
}

\begin{abstract}
Abstrak: Keterampilan abad 21 terdiri dari keterampilan communication, collaboration, critical thinking and problem solving, serta creative and inovative. Keterampilan ini perlu di implementasikan guru dalam proses pembelajaran agar kualitas pembelajaran meningkat. Terbatasnya pengetahuan guru terhadap keterampilan pembelajaran abad 21 menjadi kendala pelaksanaan di dalam kelas. Oleh karena itu, perlu upaya pengenalan keterampilan pembelajaran abad 21 ini kepada guru agar dapat diimplementasikan dengan baik di kelas. Kegiatan pengabdian masyarakat ini dilaksanakan di MTs Massaratul Muta'allimin Banten dengan jumlah peserta sebanyak 8 guru. Kegiatan ini bertujuan untuk mengoptimalkan pemahaman guru terhadap keterampilan pembelajaran abad 21 dan cara mengimplementasikannya dalam proses pembelajaran. Pengabdian ini dilakukan dengan cara sosialisasi melalui penyampaian materi kemudian dilakukan evaluasi di akhir kegiatan yang terdiri dari tiga tahapan yaitu tahap awal, inti, dan akhir. Berdasarkan hasil angket di akhir kegiatan diperoleh data bahwa $78,13 \%$ guru memahami cara penyampaian materi, $78,13 \%$ guru dapat memahami materi dengan baik, $82,29 \%$ guru memberikan respon terhadap manfaat kegiatan, dan $81,25 \%$ guru dapat mengembangkan proses pembelajaran abad 21 di kelas. Dapat disimpulkan bahwa kegiatan pengabdian ini dapat mengoptimalkan pemahaman guru di MTs Massaratul Muta'llimin Banten terhadap keterampilan pembelajaran abad 21.
\end{abstract}

Kata Kunci: keterampilan abad 21, communication, collaboration, critical thinking and problem solving, creative and inovative

\begin{abstract}
The 21st Century skills consist of communication, collaboration, critical thinking, and problem-solving skills, as well as creative and innovative. This skill needs to be implemented by the teachers in the learning process so that the quality of learning increases. The limitation of teachers' knowledge of 21st-century learning skills is an obstacle for implementation in the classroom. Therefore, it is necessary to introduce this 21st-century learning skill to the teachers so that it can be implemented well in the classroom. This community service program was carried out at MTs Massaratul Muta'allimin Banten with eight teachers as the participants. It aims to optimize teachers' understanding of 21st-century learning skills and how to implement them in the learning process. This program was held by means of socialization through the delivery of material then an evaluation was administered at the end of the activity in three stages namely the initial, core, and final stages. The results of the questionnaire at the end of the activity show that $78.13 \%$ of teachers understand how to deliver the material, $78.13 \%$ of teachers can understand the material well, $82.29 \%$ of teachers respond to the benefits of the activity, and $81.25 \%$ of teachers can develop 21st-century based learning process in the classroom. It can be concluded that this program can optimize teachers' understanding of 21stcentury learning skills.
\end{abstract}

Keywords: 21st century skills; communication, collaboration, critical thinking and problem solving, creative and innovative

\section{Pendahuluan}

Abad 21 disebut juga dengan abad revolusi industri 4.0, abad perkembangan ilmu pengetahuan dan teknologi yang begitu cepat. Perkembangan ilmu pengetahuan yang begitu cepat menuntut siswa harus mampu beradaptasi dan mengikuti perkembangan tersebut. 
Perkembangan yang begitu cepat mempengaruhi berbagai aspek termasuk juga pada aspek pendidikan, untuk itu perlu kesiapan siswa dalam menghadapinya. $21^{\text {th }}$ century readiness (kesiapan abad 21) merupakan kesiapan dalam menyambut abad 21. UNESCO telah membuat empat pilar pendidikan untuk menghadapi abad 21, yaitu:(1) learning to how (belajar untuk mengetahui), (2) learning to do (belajar untuk melakukan), (3) learning to be (belajar untuk mengaktualisasikan diri sebagai individu mandiri yang berkepribadian), (4) learning to live together (berjalan untuk hidup bersama) (Sasmoko, 2017). Keempat pilar tersebut menjadi dasar dalam keterampilan abad 21. Keterampilan abad 21 yang sangat diperlukan oleh lulusan untuk berprestasi dan berkompetisi di abad 21 telah diidentifikasi oleh The Partnership for $21^{\text {st }}$ Century Skills. Keterampilan ini dapat meningkatkan kemampuan daya jual (Marketability), kemampuan bekerja (Employbility) dan kesiapan menjadi warga negara (readiness for citizenship) yang baik (Redhana, 2019).

Kementerian Pendidikan dan Kebudayaan Republik Indonesia telah mengadaptasi tiga konsep pendidikan abad 21 dalam rangka mengembangkan kurikulum baru baik untuk SD, SMP,

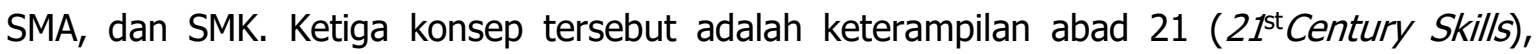
pendekatan saintifik (scientific approach) dan penilaian autentik (auntentik assessment) (Lilis, 2017). Pembelajaran abad 21 merupakan peralihan pembelajaran yang menuntut perubahan pendekatan pembelajaran yang berpusat pada pendidik (teacher centered learning) menjadi pendekatan pembelajaran yang berpusat pada peserta didik (student centered learning).

Ciri-ciri abad 21 akan menghasilkan karakter pembelajaran abad 21, dan berdampak penilaian abad 21 . Ciri yang paling mencolok pada abad 21 adalah adanya multitasking (multitasking), multimedia (multimedia), online social networking (jejaring media sosial daring), online in for searching (pencarian daring), gameonline (permainan daring) (Eny, 2018). Dalam proses pembelajaran keterampilan abad 21 dikenal dengan keterampilan $4 C$ yaitu kreativitas (creativity), berpikir kritis (critical thinking), komunikasi (communication), kolaborasi (collaboration). Keterampilan Abad 21 sangat penting untuk membelajarkan pengetahuan secara mendalam dan menunjukkan pemahaman melalui kinerja (Muhali, 2019). Penerapan 4C dalam pembelajaran kurikulum 2013 jika benar-benar dilakukan di sekolah akan memberikan dampak yang luar biasa bagi generasi penerus bangsa untuk menghadapi tantangan hidup abad 21 (Lina, Alrahmat, \& Mursalin, 2018).

Sedangkan Partnership for $21^{\text {st }}$ Century Skills mengidentifikasi keterampilan abad 21 meliputi: berpikir kritis dan pemecahan masalah, kreativitas dan inovasi, komunikasi dan kolaborasi. Berpikir kritis berarti siswa mampu mensikapi ilmu dan pengetahuan dengan kritis, mampu memanfaatkan untuk kemanusian. Terampil memecahkan masalah berarti mampu mengatasi permasalahan yang dihadapinya dalam proses kegiatan belajar sebagai wahana berlatih menghadapi permasalahan yang lebih besar dalam kehidupannya. Keterampilan kreativitas dan inovasi merupakan keterampilan dalam menemukan, mengemukakan gagasan baru dengan cara yang berbeda atau baru. Keterampilan komunikasi merujuk pada kemampuan mengidentifikasi, mengakses, memanfaatkan dan mengoptimalkan perangkat dan teknik komunikasi untuk menerima dan menyampaikan informasi kepada pihak lain. Terampil kolaborasi berarti mampu menjalin kerjasama dengan pihak lain untuk meningkatkan sinergi (Harli, 2013). 
Keterampilan abad 21 sangat penting untuk dikembangkan berdasarkan National Education Asociation (NEA) merekomendasikan tentang pentingnya pengembangan "Four CS. Four Csyang dimaksud adalah: (1) Critical thinking and problem solving, di dalamnya mencakup kemampuan berargumen secara efektif, berpikir sistemik, membuat pembenaran dan keputusan, dan memecahkan masalah. (2) Communication, mampu menyampaikan pikiran dan gagasan secara efeltif dalam bentuk oral, tulis, dan non verbal lainnya, terampil mendengar (listening skills), mampu menggunakan perangkat komunikasi secara efektif dan fungsional, mampu berkomunikasi dengan berbagai kalangan, berbagai tujuan, dan berbagai konteks budaya. (3) Collaboration, kemampuan bekerja secara efektif dalam tim, fleksibel dan mau membantu untuk berkompromi demi tercapainya tujuan bersama, dan mampu berbagi tanggung jawab dan menghargai kontribusi dari anggota tim. (4) Creativity and Innovation, adalah kemampuan untuk berpikir kreatif, bekerja secara kreatif dengan yang lain, mampu mengimplementasikan ide-ide kreatif dalam praktik (Ferdinandus \& Desak, 2018).

Kemampuan pendidik (guru) sangat menunjang keberhasilan keterampilan abad 21. Kemampuan tersebut tertuang dalam profil pendidik yaitu profil pendidik abad 21 yang pertama adalah knowladge (pengetahuan) yakni kemampuan intelektual yang dimiliki seorang pendidikan yang meliputi pengusaan materi pelajaran, pengetahuan mengenai cara mengajar, pengetahuan mengenai belajar dan tingkah laku individu, pengetahuan tentang bimbingan dan penyuluhan, pengetahuan tentang kemasyarakatan dan pengetahuan umum, kedua perfomance criteria erat kaitanya dengan kemampuan pedagogis (keterampilan dan prilaku) pendidik yakni kemampuan pendidik yang meliputi keterampilan mengajar, membimbing, menilai, menggunakan alat bantu pengajaran, bergaul dan berkomunikasi dengan peserta didik dan keterampilan menyusun persiapan mengajar atau perencanaan mengajar. Ketiga, product criteria yakni berkaitan dengan bagaimana proses pengukuran pendidik tentang hasil belajar siswa pada pembelajaran abad 21 (Rayinda, 2019). Disamping itu kompetensi guru abad 21 terdiri dari kompetensi digital age literacy, inventive thinking, effective communication, dan high productivity (Yulianisa, Fahmi, Oktaviani \& Rijal, 2018).

Berdasarkan hasil observasi di MTs Masaratul Mut'allimin Banten,dalam proses pembelajaran guru belum sepenuhnya menerapkan keterampilan pembelajaran abad 21 , hal ini disebabkan oleh terbatasnya pengetahuan guru terhadap konsep dan implementasi keterampilan abad 21.Guru masih menggunakan pembelajaran secara konvensional atau pembelajaran dengan menggunakan metode yang sudah biasa diterapkan. Permasalahan berikutnya adalah kemampuan siswa, guru masih berpendapat bahwa dengan menggunakan pembelajaran konvensional siswa masih kesulitan memahami materi, sedangkan guru belum berupaya melakukan inovasi metode pembelajaran. Media pendukung pembelajaran juga menjadi kendala penggunaan inovasi metode pembelajaran.

Kurikulum 2013 menuntut guru untuk mampu mengembangkan keterampilan abad $21 \mathrm{di}$ dalam proses pembelajaran yang bertujuan menciptakan generasi emas dalam bersaing secara universal atau secara langsung menciptakan pendidikan yang bermutu. Kurikulum 2013 dirancang dan dikembangkan untuk memfasilitasi baik guru maupun siswa terampil dalam meningkatkan interaksi pembelajaran terutama pembalajaran berbasis aktivitas seperti pembelajaran abad 21 . 
Berdasarkan kajian di atas keterampilan pembelajaran abad 21 sangat penting dikembangkan hal ini bertujuan untuk meningkatkan kemampuan siswa yang bersifat kognitif dan afektif agar mampu bersaing dan mengikuti perkembangan memalui proses kecakapan abad 21. Keterampilan abad 21 menjadi tantangan sendiri bagi guru dan siswa agar mampu beradaptasi dengan era saat ini. Untuk itu guru harus melakukan perubahan terhadap pola pembelajaran dari yang bersifat konvensional ke pola pembelajaran yang bersifat inovatif yang dibutuhkan oleh siswa saat ini. Mengembangkan keterampilan abad 21 menjadi tanggung jawab guru sebagai pencetak generasi yang dibutuhkan oleh negara secara umum maupun lingkungan kehidupan siswa sehari-hari. Keterampilan abad 21 perlu di integrasikan dan di implementasikan dalam pembelajaran dengan tujuan untuk menciptakan generasi yang terampil sesuai dengan kebutuhan dan tuntutan saat ini. Sehingga mendorong terwujudnya bangsa Indonesia yang maju dan mampu bersaing dengan bangsa lain.

Secara umum tujuan pelaksanaan kegiatan pengabdian kepada masyarakat adalah mengoptimalkan keterampilan pembelajaran abad 21 dalam proses pembelajaran oleh guru MTs Massaratul Muta'allimin Banten melalui kegiatan sosialisasi tentang konsep dan implementasinya di dalam pembelajaran.Guru MTs Massaratul Muta'allimin Banten dijadikan sebagai partisipan kegiatan PKM karena masih terbatasnya pengetahuan guru terhadap pelaksanaan keterampilan pembelajaran abad 21 . Kegiatan ini penting dilakukan karena terkait dengan kemajuan pendidikan yang bertujuan untuk meningkatkan pendidikan yang bermutu terutama pendidikan di wilayah Banten.

\section{Metode}

Kegiatan pengabdian kepada masyarakat ini dilakukan dalam bentuk sosialiasi melalui pemaparan materi kemudian dilakuan evaluasi terhadap pemahaman peserta. Evaluasi yang dilakukan berupa pengumpulan data dengan cara pemberian angket kepada peserta. Pemberian angket dilakukan untuk melihat persentase pemahaman peserta terhadap pemberian materi dan implementasi tentang keterampilan pembelajaran abad 21. Dengan rincian kegiatan sebagai berikut.

\section{Tahap Awal}

Kegiatan dimulai dengan melakukan studi lapangan untuk mengetahui lokasi dan kondisi MTs Massaratul Muta'allimin Banten. Tim Pengabdian Kepada Masyarakat (PKM) melakukan observasi dengan pihak sekolah terkait masalah yang dihadapi para guru dalam melaksanakan pembelajaran di kelas. Dari hasil wawancara diperoleh informasi bahwa masih banyak guru yang belum memiliki pengetahuan yang luas tentang jenis-jenis pembelajaran yang dapat diterapkan di kelas terutama pembelajaran yang sesuai dengan tuntutan kurikulum 2013. Kemudian tim PKM memberikan solusi dengan mengusulkan kegiatan pengenalan keterampilan pembelajaran abad 21.

Setelah berdiskusi dalam menentukan tanggal dan waktu pelaksanaan kegiatan maka diputuskan bahwa kegiatan ini dilaksanakan pada tanggal 18 Januari 2020. Selanjutnya tim PKM 
melakukan kajian untuk mengumpulkan berbagai literature dan menyusun materi yang akan disampaikan pada kegiatan ini.

\section{Tahap Inti}

Inti dari kegiatan pengabdian kepada masyarakat ini adalah dilakukannya sosialisasi kepada para guru di MTs Massaratul Muta'allimin Banten mengenai pengenalan keterampilan pembelajaran abad 21. Terkait materi keterampilan pembelajaran abad 21, para guru diberikan pemahaman mengenai apa itu pembelajaran abad 21, bagaimana pelaksanaannya di kelas serta mengapa kita sebagai guru harus mampu menerapkan keterampilan pembelajaran abad 21 saat ini. Dalam pemaparannya, pemateri tidak hanya berceramah secara satu arah akan tetapi lebih banyak memberikan ruang diskusi dengan memberikan kesempatan kepada para guru untuk menyampaikan pandangannya, pengalamannya selama mengajar di kelas.

Pemateri juga menyisipkan video mengenai keterampilan pembelajaran abad 21 yang dapat disaksikan oleh peserta untuk memperdalam pemahaman mereka terkait dengan keterampilan pembelajaran abad 21. Para guru yang menjadi peserta dalam kegiatan ini cukup antusias dan fokus memperhatikan tiap pokok materi yang disampaikan. Pada bagian akhir, terdapat sesi tanya jawab yang memberikan kesempatan kepada para guru untuk memberikan pertanyaan ataupun sanggahannya terkait materi yang telah disampaikan.

\section{Tahap Akhir}

Diakhir kegiatan, tim dosen menyebarkan angket yang diisi oleh para guru peserta kegiatan untuk mengukur pemahaman peserta dalam beberapa aspek diantaranya yaitu aspek penyampain materi, aspek konten/isi materi, aspek manfaat manfaat kegiatan, dan umpan balik (feedback). Angket berisi 10 butir pernyataan yang meliputi, 2 butir mengukur pemahaman peserta pada aspek penyajian materi, 2 butir mengukur aspek konten/isi materi, 3 butir mengukur aspek manfaat kegiatan dan 3 butir untuk mengukur umpan balik (feedback) peserta terhadap kegiatan ini. Angket diisi menggunakan skala Likert dengan cara memberikan tanda ceklis pada kolom pilihan yang tersedia yaitu SS (Sangat Setuju), S (Setuju), TS (Tidak Setuju), dan Sangat Tidak Setuju (STS). Dibagian akhir angket, peserta dapat menuliskan kritik dan saran demi perbaikan kegiatan ini berikutnya. Alur kegiatan dapat dilihat di Bagan 1.

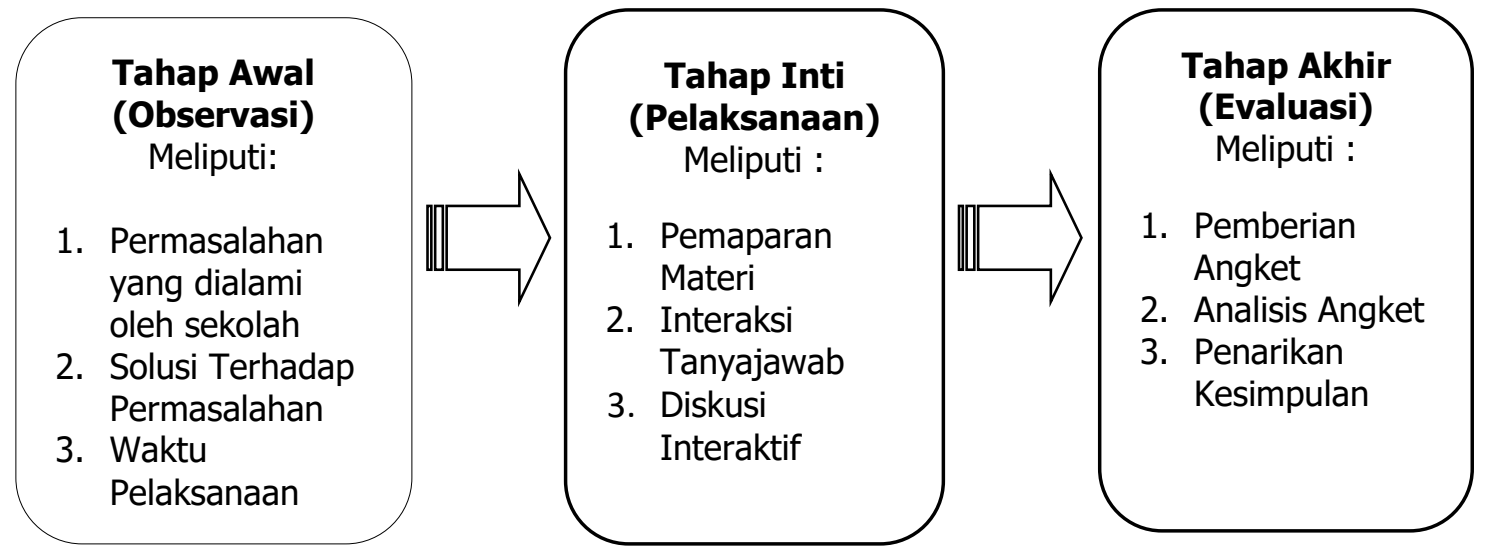

Bagan 1. Kerangka Kegiatan PKM 


\section{Hasil dan Pembahasan}

Kegiatan pengabdian kepada masyarakat dilakukan melalui tiga tahapan yaitu tahap awal berupa observasi permasalahan yang dialami oleh mitra PKM, hasil dari tahap awal berupa identifikasi permasalahan, solusi serta jadwal pelaksanaan kegiatan PKM.Tahap inti pelaksanaan kegiatan PKM berupa penyampaian materi serta pembahasan implementasi keterampilan pembelajaran abad 21. Pada tahap ini hasil kegiatan berupa interaksi tanyajawab serta diskusi tentang proses keterampilan pembelajaran abad 21. Tahap akhir dari kegiatan berupa pemberian angket yang bertujuan untuk melihat sejauh mana keberhasilan proses pelaksanaan PKM. Hasil angket tentang pengenalan keterampilan pembelajaran abad 21 disajikan dalam Tabel 1.

Tabel 1. Rekapitulasi Hasil Angket Pemahaman Peserta

\begin{tabular}{ccccccccccc}
\hline \multirow{2}{*}{ Responden } & \multicolumn{10}{c}{ Butir Pernyataan } \\
\cline { 2 - 10 } & 1 & 2 & 3 & 4 & 5 & 6 & 7 & 8 & 9 & 10 \\
\hline A & 3 & 3 & 3 & 3 & 3 & 3 & 3 & 3 & 3 & 3 \\
B & 4 & 3 & 3 & 3 & 4 & 3 & 3 & 3 & 3 & 3 \\
C & 3 & 2 & 3 & 3 & 3 & 3 & 3 & 3 & 3 & 3 \\
D & 4 & 2 & 3 & 2 & 4 & 4 & 3 & 4 & 3 & 4 \\
E & 3 & 4 & 3 & 4 & 4 & 3 & 4 & 3 & 4 & 4 \\
F & 4 & 3 & 4 & 3 & 3 & 4 & 4 & 3 & 3 & 4 \\
G & 3 & 3 & 3 & 3 & 3 & 3 & 3 & 3 & 3 & 3 \\
H & 3 & 3 & 4 & 3 & 3 & 3 & 3 & 3 & 4 & 3 \\
\hline
\end{tabular}

\section{Keterangan:}

Aspek tentang pemahaman peserta terhadap:

1. Penyampaian Materi (Butir No.1 dan 2)

2. Konten/Isi Materi (Butir No.3 dan 4)

3. Manfaat Kegiatan (Butir No. 5, 6 dan 7)

4. Umpan Balik/ Feedback (Butir No. 8, 9, dan 10)

Dari hasil angket diperoleh, 2 butir mengukur pemahaman peserta pada aspek penyajian materi pada aspek pernyataan 1 diperoleh $84,375 \%$ peserta menyampaikan materi yang diberikan menambah wawasan tentang pembelajaran abad 21, item pernyataan 2 diperoleh $71,875 \%$ peserta menanggapi penyajian materi cukup interaktif, 2 butir mengukur aspek konten/isi materi yang terdiri item pernyataan 3 diperoleh $81,25 \%$ materi yang disajikan membantu guru meningkatkan wawasan tentang pembelajaran abad 21 , item pernyataan 4 diperoleh $75 \%$ peserta menanggapi bahan materi mengandung unsur interaktif.

Berikutnya 3 butir mengukur aspek manfaat kegiatan yaitu item pernyataan 5 diperoleh $84,375 \%$ peserta menanggapi kegiatan ini dapat meningkatkan keterampilan dalam menerapkan pembelajaran abad 21, item pernyataan 6 diperoleh $81,25 \%$ peserta dapat meningkatkan kemampuan mengembangan kecakapan pembelajaran abad 21 , item pernyataan 7 diperoleh $81,25 \%$ peserta menanggapi bahwa kegiatan ini sangat menunjang pembelajaran saat ini, 3 butir untuk mengukur umpan balik (feedback) yaitu :item pernyataan 8 diperoleh $78,125 \%$ peserta akan berusaha mengembangkan pembelajaran abad 21 secara efesian dan efektif dalam pembelajaran di kelas, item pernyatan 9 diperoleh $81,25 \%$ peserta menanggapi kegiatan ini membantu guru dalam meningkatkan kompetensi profesional, item pernyatan 10 
diperoleh $84,375 \%$ peserta termotivasi untuk terlibat aktif mengikuti kegiatan sejenis untuk berikutnya. Persentase hasil angket pemahaman peserta terhadap materi ditinjau dari aspek yang diukur disajikan dalam Tabel 2.

Tabel 2. Persentase Angket Pemahaman Peserta

\begin{tabular}{clc}
\hline No & Aspek yang diukur & Persentase \\
\hline 1 & Penyampaian Materi & $78,13 \%$ \\
2 & Konten/Isi Materi & $78,13 \%$ \\
3 & Manfaat Kegiatan & $82,29 \%$ \\
4 & Umpan Balik/Feedback & $81,25 \%$ \\
\hline
\end{tabular}

Dari Tabel 2 di atas terlihat bahwa pemahaman peserta terhadap pengenalan pembelajaran abad 21 baik sekali. Hal ini terlihat dari hasil angket yang ditinjau dari aspek yang diukur melebihi $75 \%$. Aspek penyampaian materi diperoleh 78,13\% artinya dari segi penyampaian materi tersampaikan dengan baik dan interaktif. Aspek konten/isi materi diperoleh $78,13 \%$ artinya isi materi membangun pengetahuan guru. Aspek manfaat kegiatan diperoleh $82,29 \%$ artinya guru sangat merasakan kebermanfaatan atas materi yang disampaikan. Aspek umpan balik/feedback diperoleh $81,25 \%$ artinya respon guru terhadap pelaksanaan sangat baik dan memotivasi guru dalam melaksanakan pembelajaran abad 21 di kelas masing-masing. Secara umum respon guru terhadap pelaksanaan kegiatan PKM tergolong baik, akan tetapi perlu peningkatan yang lebih baik supaya materi dalam kegiatan ini dapat dipahami dengan baik oleh peserta dan dapat di implementasikan di dalam proses pembelajaran di kelas masing-masing. Catatan penting dalam kegiatan pengabdian kepada masyarakat ini adalah guru sangat terbantu dan termotivasi dalam menerapkan pembelajaran di kelas karena guru memiliki bekal yang kuat dengan adanya pendampingan berupa penyampaian materi, pemberian contoh-contoh dan pembahasan permasalahan-permasalahan yang terjadi di kelas masing-masing. Kegiatan ini sangat membantu guru dalam menerapkan keterampilan pembelajaran abad 21 di kelas. Hal ini terlihat dari antusias dan semangat guru dalam mengikuti kegiatan PKM. Kegiatan PKM memberikan kontribusi terhadap pemahaman konsep dan implementasi keterampilan pembelajaran abad 21 guru-guru di MTs Massaratul Muta'llimin Banten.

Berdasarkan hasil angket bahwa persentase pemahaman peserta baik sekali, hal ini terlihat dari proses pengenalan dan implementasi keterampilan pembelajaran abad 21 sebagai berikut. Pada Gambar 1, terlihat bahwa tim melakukan kegiatan penyampain materi tentang keterampilan pembelajaran abad 21 , dimulai dari penyampain 4 pilar pendidikan sebagai landasan atau pijakan seorang guru dalam melakukan pembelajaran. Dilanjutkan dengan pemberian materi tentang defenisi keterampilan pembelajaran abad 21 beserta tantangannya, kemudian dilanjutkan dengan penyampaian materi keterampilan kecakapan abad 21 yang dikenal dengan keterampilan 4 Cs beserta contoh konkretnya.

Penyampaian materi tentang implementasi keterampilan pembelajaran abad 21 berupa penyampaian dari masing-masing keterampilan abad 21, dimulai dari keterampilan communication, collaboration, critical thinking and problem solving, creativity thinking and innovation. Contoh keterampilan communication berupa diskusi untuk mengolah dan memperoleh informasi, mengemukakan pendapat atau sanggahan serta memberikan masukan 
terhadap pendapat orang lain, menuliskan laporan hasil diskusi melalui tulisan, lisan ataupun dalam bentuk penyajian. Contoh keterampilan collaboration berupa bekerjasama dalam kelompok dengan cara pembagian peran dan tanggung jawab masing-masing anggota kelompok terhadap tugas menentukan pola bilangan dari suatu barisan.

Keterampilan critical thinking and problem solving berupa mengamati permasalahan yang disajikan berkaitan dengan konsep nilai mutlak dan penyelesaian persamaan maupun pertidaksamaan nilai mutlak bentuk linier satu variabel. Contoh bahan pengamatan sebagai berikut "Kegiatan pramuka merupakan salah satu kegiatan ekstrakurikuler yang diadakan di sekolah. Suatu pasukan pramuka sedang belajar baris berbaris di lapangan sekolah pada hari Sabtu. Sebuah perintah dari pimpinan regu yaitu maju 4 langkah jalan!, hal ini berarti jarak pergerakan barisan adalah 4 langkah kedepan. Jika perintah pimpinan regu adalah mundur 3 langkah jalan!, hal ini berarti bahwa pasukan akan bergerak ke belakang sejauh 3 langkah. Demikian seterusnya" (Direktorat Pembinaan SMA, Kemendikbud, 2017). Contoh keterampilancreativity thinking and innovation berupa proses diskusi untuk mengolah informasi yang diperoleh dari gambar atau poster, serta mengimplementasikan konsep atau pengetahuan dalam membuat suatu contoh permasalahan dan penyelesaiannya. Serta menganalisa dan mengambil kesimpulan berdasarkan teori yang ada pada referensi.

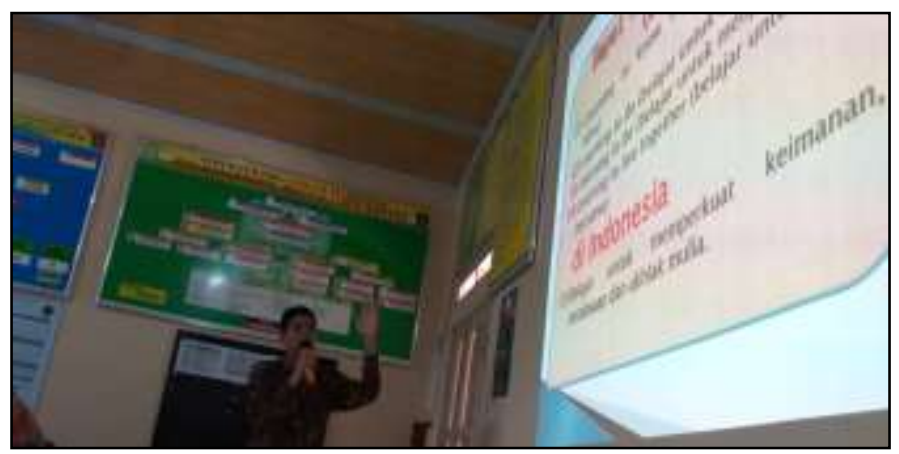

Gambar 1. Pemberian Materi Tentang Keterampilan Pembelajaran Abad 21

Pada Gambar 2, interaksi antara tim PKM dengan peserta berupa tanya jawab tentang konsep dasar pembelajaran abad 21, implementasinya di kelas, kemudian kendala-kendala yang dihadapi. Pertanyaan yang paling mendasar berupa bagaimana menumbuhkan minat dan motivasi siswa sehingga mampu melakukan kegiatan keterampilan pembelajaran abad 21 dengan baik. Kemudian kesiapan guru dalam menerapkan keterampilan pembelajaran abad 21 .



Gambar 2. Interaksi berupa tanya jawab 
Pada Gambar 3, berupa diskusi tentang permasalahan-permasalah yang dialami dalam proses pembelajaran yang selama ini dilaksanakan di dalam kelas masing-masing. Diskusi berupa permasalahan kemampuan siswa yang bervariasi atau heterogen, sarana dan prasarana yang terbatas. Ketersedian waktu dan pengelolaan keterlaksanan pembelajarannya di kelas.

Proses tanya jawab sangat interaktif karena pertanyaan berupa permasalahan atau kendala-kendala yang dihadapi guru dalam melaksanakan suatu model pembelajaran. Kendalanya berupa menyiapkan rencana pembelajaran, menentukan contoh-contoh yang relevan dengan konsep, serta permasalahan kesiapan siswa dalam menerima materi yang sesuai dengan prosedur model pembelajaran tersebut. Solusi yang ditawarkan adalah pemberian contoh-contoh dari suatu materi diambil dari konteks yang terdekat dengan siswa yang ada di lingkungan tempat tinggal mereka. Serta penyampaian contoh dimulai dari hal yang sederhana sampai kepada tingkatan yang lebih kompleks. Berkaitan dengan rencana pembelajaran diberikan satu contoh rencana pelaksanaan pembelajaran (RPP) tentang keterampilan pembelajaran abad 21 . Berkaitan dengan kemampuan siswa yang bervariasi atau heterogen yang menjadi permasalahan adalah bagaimana menstimulus siswa yang berkemampuan rendah, solusi yang ditawarkan adalah membentuk kelompok yang bersifat heterogen sehingga siswa yang berkemampuan tinggi dapat membantu siswa yang berkemampuan rendah dengan cara memberikan lembar kerja siswa yang dikerjakan secara berkelompok. Keterbatasan sarana dan prasarana dapat dilakukan dengan cara menggunakan benda-benda atau alat peraga yang ada di lingkungan sekolah atau tempat tinggal.



Gambar 3. Diskusi tentang permasalahan yang terjadi di kelas

\section{Kesimpulan}

Dari kegiatan pengabdian kepada masyarakat yang dilakukan diperoleh data bahwa pemahaman guru mengenai keterampilan pembelajaran abad 21 menjadi lebih baik berdasarkan hasil evaluasi angket yang diberikan kepada peserta. Dengan demikian dapat disimpulkan bahwa kegiatan PKM dapat mengoptimalkan pengetahuan guru di MTs Massaratul Muta'llimin Banten terhadap keterampilan pembelajaran abad 21. Sebaiknya kegiatan pengabdian kepada masyarakat ini dapat berlanjut dan dilakukan secara berkesinambungan guna memberikan manfaat serta kontribusi yang lebih nyata kepada mitra. 


\section{Ucapan Terima Kasih}

Tim penulis mengucapkan terima kasih kepada Lembaga Penelitian dan Pengabdian kepada Masyarakat (LP2M) Universitas Bina Bangsa Banten yang telah memfasilitasi kegiatan pengabdian ini sehingga terlaksana dengan baik. Tim penulis mengucapkan terima kasih kepada Ketua Yayasan serta kepala sekolah MTs Massaratul Muta'allimin Banten yang telah memfasilitasi kegiatan pengabdian ini sehingga terlaksana dengan baik.

\section{Referensi}

Direktorat Pembinaan SMA, Direktorat Jendral Pendidikan Dasar Dan menengah, Kementerian Pendidikan Dan Kebudayaan. (2017). Implementasi Pengembangan Kecakapan Abad 21 Dalam Perencanaan Pelaksanaan Pembelajaran (RPP).

Eny, W. (2018). Penilaian Kompetensi Siswa Abad 21. Seminar Nasional Edusaintek, 6-19.

Ferdinandus, B., S., \& Desak, M., A. (2018). Inovasi Pembelajaran Elektronik dan Tantangan Guru Abad 21. Jurnal Penelitian dan Pengkajian IImu Pendidikan: e-Saintika, 2(1), 10-18.

Harli, T. (2013). Strategi Pembelajaran Abad 21. Lembaga Penjamin Mutu Pendidikan Prov. D.I. Yogyakarta (Artikel web). Diakses di http://lpmpjogja.kemendikbud.go.id/strategipembelajaran-abad-21/).

Lilis, P. (2017). Redesain Pembelajaran Pendidikan Islam Dalam Perspektif Pembelajaran Abad 21. JPSD: Jurnal Pendidikan Sekolah Dasar, 3(2), 34-42.

Lina, S., Alrahmat, A., \& Mursalin. (2018). Pembelajaran Abad 21 Di SD. Prosiding Seminar dan Diskusi Nasional Pendidikan Dasar, 439-444.

Muhali. (2019). Pembelajaran Inovatif Abad Ke-21. Jurnal Penelitian dan Pengkajian IImu Pendidikan: e-Saintika, 3(2), 25-50.

Rayinda, D., P., \& Rio, E. (2019). Kecakapan Abad 21: Kompetensi Digital Pendidik Masa Depan. Jurnal Manajemen Pendidikan, 14(2), 144-151.

Redhana, I.W. (2019). Mengembangkan Keterampilan Abad Ke-21 Dalam Pembelajaran Kimia. Jurnal Inovasi Pendidikan Kimia, 13(1), 2239-2253.

Sasmoko. (2017). Pendidikan Abad 21. Pendidikan Guru Sekolah Dasar Binus University (Artikel web). Diakses di http://pgsd.binus.ac.id/2017/08/08/pendidikan-abad-21/.

Yulianisa, Fahmi, R., Oktaviani, \& Rijal, A. (2018). Tinjauan Keterampilan Abad 21 (21 st Century Skills) di Kalangan Guru Kejuruan (Studi kasus: SMK Negeri 2 Solok). Cived Jurusan Teknik Sipil, 5(3), 1-8. DOI: https://doi.org/10.24036/cived.v5i3.102505 